(66) 医器学 Vol. 54, No. 4 (1984)

化学的指標としては汸販の I C Eカードを用いた.

EOガスはエポンおよびダイサイドLとし，封入用 袋は 75 80 $\mu$ の八イゼックスの容量約 $10 l$ の大きさ のものを用いた、また封入ガスの経時変量の測定は, 袋にゴム板をはり，そこをサンプリング孔としてシリ ンジで採取し，ガスクロマトグラフ法によった。

[結果]袋中の E Oガス濃度は袋によってバラツキ， $1 \sim 2$ 時閒の間に半量近くまで減少した.この減少率 は，温度が高いほど大きくなる傾向が認められた，殺 菌効率は, 保管温度に依存するが, 被滅菌物の種類 （公定水分率の差を含む）・量によっても変化する傾 向が認められた。

\section{1. 院内感染防止のための抗菌性アクリル繊 維の応用}

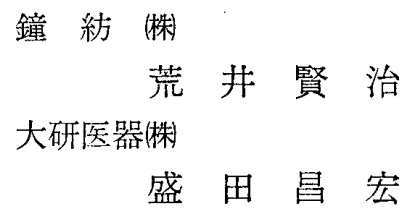

リブフレッシュAは, 纎維そのものに抗菌力を付与 したアクリル䋐維である。繊維の中の毒性の少ない抗 菌荗（イルガサンD P 300，チバガイギー）を練りこ み, 微量の抗菌剤が繊維表面に存在する方式をとった ものである.薬剤は $2,4,4^{\prime}$-trichloro-2'-hydroxy diphenylether である (イルガサンD P 300).

1）イルガサンD P 300 の抗菌力：薬剤自身での測定 によるとMIC值 (ppm) にて, St. aureus (0.01 0.1) B. subtilis $(0.1)$, St. faecalis $(3 \sim 10)$, E. coli $(0.1$ $\sim 0.3$ ), Kleb. pneumoniae (0.3), Neisseria spp (33), Trich. mentagrophytes (1), C. albicans (3), Asp. niger (30) など, グラム陽性・陰性菌, 真菌に対し幅 広い抗菌スペクトルを示すが，Pseudomonas spp に 対しては効果は少ない。

2）リブフレッシュAの特徵：この繊維は繊維の中に 抗菌刘を含み，表面はもとより内部まで抗菌力を有す る. その抗菌剂恃繊維内部から表面一と, 局所的な密 度ムラを修正しながら繊維表面へと移動するので抗菌 剤表面密度はいっも一定の值をとる. 従って抗菌効果 は長期間持続する.

3）耐久性：本繊維は不織布および織編物に加工可能 であり，その洗濯耐久性は，50回洗濯繰り返しで薬剂 含有量が $10 \%$ 前後しか減少しない，一方薬㓮自身は， $200^{\circ} \mathrm{C} \times 14$ 時間で $2 \%$ しか分解せず構造的に安定であ る.繊維に含有する薬剂は高温度では散逸が起こる $\left(140^{\circ} \mathrm{C} \times 5\right.$ 分で $15 \%$ 減)， $100^{\circ} \mathrm{C}$ 以下では安全である. 4）安全性: 薬剤自身は経口, 経皮投与から発ガン性, 繁殖試験, 代謝試験に至る安全性が破認されている。 マウス 1 回投与 $\mathrm{L}_{50}$ 值は $4500 \mathrm{mg} / \mathrm{kg}$ である. 本リ ブフレッシュAとしては, 皮膚貼付試験, 変異原性試 験，局所刺激試験が行われ安全が確認されている.

\section{2. ポリオレフィン多孔質中空糸膜の特性を 応用した多目的滅菌浄水器の開発}

和歌山県衛生公害研究センター 神木照雄 三菱レイヨン侏

沢田洋介河合厚 藤井礼子 井上通生 伊神生雄

われわれはポリエチレン多孔質中空采膜を用いた超 精密沪過装置「ステラポアー」を開発し, 病院手術室 の手洗い用水などで好成績を抢さめているが，手洗い 用水以外の用途については，有害有機物や塩素などの 除去が必要となる場合が多い，そこで今回は，水の前 処理との組み合わせによる多目的滅菌浄水器の開発に ついて検討した.

その結果，水道水中のエンドトキシン除去効果につ いて活性炭とポリエチレン多孔質中空糸膜の相乗作用 が発現し, 中空采膜のエンドトキシン除去容量が大幅 に向上することを見出だした. さらに水道水や地下水 に微量溶存している疎水性有機物の除去についても, 両者の組み合わせが有効であることを認めた。

またシステムをコンパクトにまとめた浄水器を試作 した.

この装置によれば，小型モジュールを蛇口に直結す るのみで水道水, 地下水等の細菌, 真菌を除去し, エ ンドトキシン，疎水性有機物および塩素などの濃度を 大幅に低下させることが可能となり, 病院の薬剂室, 検查室や研究室など, 多目的の用途に有用と考えられ る.

\section{3. 酸化エチレンの血液への影響}

㸡クラレメディカル研究開発室 高 島 征 助

酸化エチレン（EOG）の血液への影響については, 溶血現象, 血球の形状の変化などについて報告されて 